\title{
Assessing the Critical Thinking Skills of Students at Higher Secondary Level
}

\author{
${ }^{a}$ Uzma Shahzadi, ${ }^{\text {b }}$ Syed Nasir Hussain, ${ }^{\mathrm{c}}$ Mubashrah Jamil \\ ${ }^{\text {a }}$ Assistant Professor, Department of Education, University of Sargodha, Pakistan \\ ${ }^{\mathrm{b}}$ Assistant Professor, ECE\&ETED, Faculty of Education, Allama Iqbal Open University Islalmabad, Pakistan \\ Email: nasir.hussain@aiou.edu.pk \\ ${ }^{\mathrm{c}}$ Assistant Professor, Department of Education, Bahaudin Zakariya University Multan, Pakistan \\ Email: mubashrahjamil@bzu.edu.pk
}

\begin{tabular}{l}
\hline ARTICLE DETAILS \\
\hline History: \\
Accepted 30 April 2021 \\
Available Online June 2021 \\
\hline Keywords: \\
Assessment, Thinking Skills, \\
Critical Thinking Skills, Critical \\
Thinking Skill Development \\
JEL Classification: \\
J24
\end{tabular}

DOI: $10.47067 /$ real.v4i2.158

\begin{abstract}
The ultimate aim of education is to develop human beings in such a way that they can act beneficial for themselves as well as for the society and can think well and think critically. Development of critical thinking skills is the fundamental aim of education. The present study intended to assess the critical thinking skills among students at higher secondary level in the province of Punjab, Pakistan. The study is quantitative in nature. Population of the study comprises students enrolled in higher secondary level in Punjab. Multistage sampling technique was used to select the sample. A self-developed multiple choice item test was used to assess the critical thinking skills among students. Expert opinion was taken to validate the test and reliability coefficient was 0.86 . It was found that majority of students did not perform satisfactory on the critical thinking skill test and scored low on all dimensions of critical thinking skills. The study concluded that curriculum and teaching methodologies along with assessment practices are not worth inculcating critical thinking skills among students. The study recommended that curriculum at higher secondary level might be redesigned and development of critical thinking skill through teaching methodologies might take into consideration by the institutes.
\end{abstract}

(C) 2021 The authors. Published by SPCRD Global Publishing. This is an open access article under the Creative Commons AttributionNonCommercial 4.0

Corresponding author's email address: nasir.hussain@aiou.edu.pk

\section{Introduction}

Critical thinking is not a new concept. The history of teaching of critical thinking skills can be traced back to Socrates. The concept is alive since 2500 years. Critical thinking is considered important in the academic fields because it enables one to analyze, evaluate, explain, and restructure their thinking, thereby decreasing the risk of adopting, acting on, or thinking with, a false belief (Sternberg, 1986; Ennis, 1989; Giancarlo \& Facione, 2001). Critical thinking skill is considered to be the high focused outcome of education across the globe. Critical thinking skill plays a great role in the personal and professional life of the individual by developing the independent thinking and problem solving skills of the individuals (Bellaera, Debney \& Baker, 2018) Critical thinking includes the component skills 
of analyzing arguments, making inferences using inductive or deductive reasoning, judging or evaluating, and making decisions or solving problems (Lai,2011). Critical thinking skill is learning to use mental processes for critical analysis and evaluation ((Proulx, 2004; Walkr, 2005; Cottrell, 2017). Critical thinking is a thinking that involves reasoning and logic to solve the problems (Page \& Mukherjee, 2006).

Pascarella and Terenzini (1991) noted that critical thinking has been defined and measured in a number of ways "but typically involves the individual's ability to do some or all of the following: identify central issues and assumptions in an argument, recognize important relationships, make correct inferences from data, deduce conclusions from information or data provided, interpret whether conclusions are warranted on the basis of the data given, and evaluate evidence or authority" (p. 118). Although the definitions and measures of critical thinking vary across the available studies, the weight of evidence is generally consistent with respect to what does and does not influence gains in students' critical thinking abilities. These skills, for example, appear not to be differentially affected by a student's academic subjects. While it is reported (Burns, 1974; Bennett, 1975; King, Wood \& Mines, 1990) that differences across academic major fields (PascareUa, 1989; Pascarella \&Terenzini, 1991) indicate these differences fade away when pre-college differences in students' critical thinking skills are taken into account.

It is evident from literature on educational planning and policies that since few decades there has been a greater shift in educational goals. Now the address of educational planning and policies are more focused on global citizenship education and education for sustainable development. The move shows the recognition of the need for equipping the learners with problem solving, critical thinking, communication and collaborative competencies by the educational institutes. The education and curricular reforms' main focus is on these "21st century goals". This all view point is promoted by global discussion of changing work and societal needs (Care, Kim, Vista \& Anderson, 2016). Education reforms suggest developing critical thinking skills among students of all levels of education in Pakistan. it is evident from the literature that the dominant thinking skill that is strongly needed in this 21st century is critical thinking skills (Kharbach, 2012). It is indicated that to develop critical thinking skills curriculum exposure, classroom teaching learning experiences, out of class experiences and assessment practices should be reframed. There are many strategies available in literature to support the development of critical thinking skills among students but still it is a challenge for both researchers and teachers to assess and develop critical thinking skills among students (Gul, Cassem, Ahmed, Khan, Saeed \&Parpio, 2010).

\section{Review of Related Literature}

In Pakistan the curriculum revision was observed in the year 2005-2006 and revision is under process (Gulzar \& Mahmood, 2018; Mahmood \& Aziz, 2018; Iqbal \& Almani, 2018). The revision has taken the standards and goals of secondary education under consideration. Assessment of Critical thinking skills and its development is a major challenge at higher secondary education in Pakistan. for example, Warsi (2004) suggested that in Pakistani classrooms, teachers are mostly focused on transferring the factual information rather than developing and assessing the critical thinking among students. Research study in relation to critical thinking skills was carried out by Rashid and Qaisar (2016) suggested that critical thinking skills is needed to address in the curriculum and can be developed by adapting questioning technique as intervention strategy. Another study by Tahir (2018) concluded that transformative teaching can develop the critical thinking skills among students in English Classrooms. 
Research Study Conducted by Akhter and Saeed (2018) concluded that Secondary School curriculum and Examination do not address the development of critical thinking ability among students who are enrolled in SSC system of Pakistani schools. Similarly, research Study conducted by Awan, Perveen and Abiodullah (2018) concluded that it can be concluded that critical thinking for citizenship education in the curriculum at secondary level was not mentioned appropriately. Similarly, all the three sources which were analyzed qualitatively viz. Textbooks, Education Policy and Curriculum Documents were not equally involved to contribute towards all the five elements/components of critical thinking for citizenship education.

There are many strategies available in literature to support the development of critical thinking skills among students but still it is a challenge for both researchers and teachers to assess and develop critical thinking skills among students (Gul, Cassem, Ahmed, Khan, Saeed \&Parpio, 2010). Literature reveals that teaching strategies that actively engage students in their learning process and foster a critical thinking disposition includes self-confidence, inquiry, analytical abilities, reasoning, and openmindedness. These strategies can be useful to infuse critical thinking as a habit of the mind. In addition to these, teaching strategies such as reflections, questioning and self-directed learning, which ask for active engagement of students in their learning, are proven to be effective in developing and promoting CT skills and dispositions (Angel, Duffey, \& Belyea, 20oo; Beeken, Dale, Enos,Yarbrough, 1997; Chenoweth, 1998; Colucciello, 1997; Cravener, 1997; Di Vito-Thomas, 2000).

\section{Methodology}

The study is quantitative in nature. It is aimed at assessing the critical thinking skills of students enrolled in higher secondary level program. The population of the study was students enrolled in the higher secondary level in province Punjab, Pakistan. Multistage sampling technique was used to select sample. In the first stage three districts, i.e., Khanewal, Vehari and Sahiwal were selected conveniently. In the second stage two government degree colleges, one for male and one for female were selected from each district randomly. From each college, 100 students were selected randomly, composing a sample size of 300. A multiple choice items test (critical thinking skills test, CTST) was developed. The CTST comprised 40 items and was administered to the students. The test was focused on following dimensions i.e., Argument mapping. Deduction from the statements, Analysis of assumptions, Analysis of variables, Analyzing Tasks and Performances, Sequencing, Scheduling .Analyze the implied relations, Analysis of situations and Drawing logical conclusion. CTST was validated by expert opinion and reliability value 0.86 was established by KR-21.

\section{Analysis}

Test was administered, responses were scored. For right answer 1 was assigned and for wrong answer o was assigned. Data was tabulated in Ms-Excel. SPSS version 22 was used to apply statistics on the data. 
Table1: Demographics of the respondents and rate of response

\begin{tabular}{|l|l|l|l|}
\hline Variable & Category & Frequency(N) & Percentage \\
\hline Gender & Male & 150 & $50 \%$ \\
\hline & Female & 150 & $50 \%$ \\
\hline & Total & 300 & $100 \%$ \\
\hline Discipline & Science & 150 & $50 \%$ \\
\hline & Arts & 150 & $50 \%$ \\
\hline Districts & Total & 300 & $100 \%$ \\
\hline & Sahiwal & 100 & $33 \cdot 3 \%$ \\
\hline & Khanewal & 100 & $33 \cdot 3 \%$ \\
\hline & Vehari & 100 & $33 \cdot 3 \%$ \\
\hline & Total & 300 & $100 \%$ \\
\hline
\end{tabular}

Table 1 represents the information about participants and their rate of response in the study.

\subsection{Assessment of Argument Mapping}

Multiple Choice items questions ranging from 1-3 in critical thinking skills test(CTST) were used to analyze student's argument mapping skill(Dimension of critical thinking skill). Maximum score for argument mapping was 3. Scores achieved, their frequency and percentages are given in table.2.

Table 2: Assessment of argument mapping (items 1-3)

\begin{tabular}{|l|l|l|}
\hline Achieved Scores & Frequency (N) & Percentage \% \\
\hline O & 218 & $72.7 \%$ \\
\hline 1 & 72 & $24 \%$ \\
\hline 2 & 10 & $3.3 \%$ \\
3 & 0 & 0 \\
\hline Total & 300 & $100 \%$ \\
\hline
\end{tabular}

Table 2 shows that out of 300 students, there are $218(72 \%)$ students who scored "o" on argument mapping of critical thinking skill test. Table reflected that $72(24 \%)$ students scored " 1 " and $10(3.3 \%)$ students scored 2 from the maximum score of " 3 " on argument mapping. Table reflects that majority of the students i.e., $72 \%$ at higher secondary level scored o and only $3.3 \%$ students scored maximum i.e. “3”.

\subsection{Assessment of Logical Deduction (4-6)}

Multiple Choice items ranging from 4-6 in critical thinking skills test (CTST) were used to analyze student's logical deduction skill. Maximum score for Deduction was 3. Scores achieved by the students, their frequency and percentages are given in table 3 
Table 3: Assessment of logical deduction (items 4-6)

\begin{tabular}{|l|l|l|}
\hline Achieved score & Frequency $(\mathrm{N})$ & Percentage $\%$ \\
\hline $\mathrm{O}$ & 162 & $54 \%$ \\
\hline 1 & 96 & $32 \%$ \\
\hline 2 & 42 & $14 \%$ \\
3 & $\mathrm{O}$ & 0 \\
\hline Total & 300 & $100 \%$ \\
\hline
\end{tabular}

Table 3 shows that out of 300 students, there are 162(54\%) students who scored "o", 96 (32\%) students scored " 1 " and 42(14\%) students scored 2 from the maximum score of 3 on logical deduction. Table reflects that majority of the students i.e., 54\% scored o and only 14\% students scored 2 from maximum score (3).

\subsection{Analysis of Assumptions (Items 7-9)}

The skill of analyzing the assumptions is another dimension of Critical thinking skill taken in this study. Multiple choice items ranging from 7-9 were used to analyze the skill of analyzing assumptions. Maximum score for the skill of analyzing assumption was 3. Scores achieved by the students, their frequency and percentages are given in table 4

\section{Table 4: Assessment of analyzing assumptions (items 7-9)}

\begin{tabular}{|l|l|l|}
\hline Achieved Scores & Frequency $(\mathrm{N})$ & Percentage $\%$ \\
\hline 0 & 161 & $53 \cdot 7 \%$ \\
\hline 1 & 103 & $34 \cdot 3 \%$ \\
\hline 2 & 24 & $8 \%$ \\
\hline 3 & 12 & $4 \%$ \\
\hline Total & 300 & $100 \%$ \\
\hline
\end{tabular}

Table 4 shows that out of 300 students, there are 161(53.7\%) students who scored "o" on questions related to the skill of analyzing assumptions. Table reflected that $103(34.3 \%)$ students scored " 1 " and 24(8\%) students scored 2 from the maximum score of 3 . There were only 12 (4\%) students who achieved maximum score. Table reflects that majority of the students i.e., 53.3\% at higher secondary level scored o and only $4 \%$ student achieved maximum score i-e 3 .

\subsection{Assessment of Analysis of Variables in a Situation (Items 10-14)}

Analysis of variables addresses the student's ability to analyze variables in a situation. Multiple choice items ranging from 10-14 were used to analyze the analysis of variable skill. The maximum achievement score in analysis of variables was 5 . The achieved scores with frequency and percentages are given in table 5 . 
Table 5: Assessment of analyzing variable (items 10-14)

\begin{tabular}{|l|l|l|}
\hline Achieved Scores & Frequency $(\mathrm{N})$ & Percentage $\%$ \\
\hline $\mathrm{O}$ & 97 & $32 \%$ \\
\hline 1 & 126 & $42 \%$ \\
\hline 2 & 52 & $17 \cdot 3 \%$ \\
\hline 3 & 16 & $5 \cdot 3 \%$ \\
\hline 4 & 8 & $2.7 \%$ \\
\hline 5 & 1 & $.3 \%$ \\
\hline Total & 300 & $100 \%$ \\
\hline
\end{tabular}

Table 5 reveals that out of 300 students, 97(32\%) students scored "o" , 126(42\%) students scored “1", 52 (17.3) students scored “2”, 16(5.3\%) students scored " 3 ", 8(2.7\%) students score "4" and only $1(.3 \%)$ students scored " 5 " from the maximum score of " 5 ". It is reflected from the table that majority of the students i-e $32 \%$ at higher secondary level scored "o" and only $1(.3 \%)$ students achieved maximum score $\mathrm{i}-\mathrm{e}$ " 5 " for the analysis of variables.

\subsection{Assessment of Analysis of tasks and performance (Items 15-19)}

The skill of analyzing the tasks and performance is another dimension of Critical thinking skill taken in this study. Multiple choice items ranging from 15-19 were used to analyze the skill of analyzing tasks and performance. Maximum score for the skill of analyzing assumption was 5 . Scores achieved by the students, their frequency and percentages are given in table 6

\section{Table 6: Assessment of analysis of tasks and performance (items 15-19)}

\begin{tabular}{|l|l|l|}
\hline Achieved Scores & Frequency $(\mathrm{N})$ & Percentage \\
\hline 0 & 93 & $31.0 \%$ \\
\hline 1 & 88 & $29 \cdot 3 \%$ \\
\hline 2 & 74 & $24.7 \%$ \\
\hline 3 & 41 & $13.7 \%$ \\
\hline 4 & 5 & $1.0 \%$ \\
\hline 5 & 1 & $.3 \%$ \\
\hline Total & 300 & $100 \%$ \\
\hline
\end{tabular}

Table 6 shows that out of 300 students, 93(31\%) students scored "o" , 88(29.3\%) students scored "1", 74(24.7\%) students scored " 2 ", 41(13.7\%) students scored " 3 ", 5(1.0\%) students scored " 4 " and only $1(.3 \%)$ students could score " 5 " from the maximum score of " 5 ". It is reflected from the table that majority of the students i-e 31\% scored "o" and only $1(.3 \%)$ students achieved maximum score i-e “5”.

\subsection{Assessment of Sequencing (Items 20-25)}

Multiple choice items ranging from 20-25 in critical thinking skills test are used to analyze student's sequencing skill. Maximum score for sequencing was 6 . Scores achieved, their frequency and percentages are given in table 7 
Table 7: Assessment of sequencing skills (items 20-25)

\begin{tabular}{|l|l|l|}
\hline Achieved Scores & Frequency $(\mathrm{N})$ & Percentage $\%$ \\
\hline $\mathrm{O}$ & 71 & 23.7 \\
\hline 1 & 94 & 31.3 \\
\hline 2 & 84 & 28.0 \\
\hline 3 & 48 & 16.0 \\
\hline 4 & 2 &, 7 \\
\hline 5 & 1 & .3 \\
\hline Total & 300 & $100 \%$ \\
\hline
\end{tabular}

Table 7 shows that out of 300 students, 71(23.7\%) students scored "o" on the question related to the ability of sequencing. The table also reveals that there are 94(31.3\%) students who scored " 1 ", $84(28.0 \%)$ students scored " 2 ", 48(16.0\%) students scored " 3 ", 2(.7\%) students scored "4" and only $1(.3 \%)$ students could score " 5 " from the maximum score of " 6 ". It is reflected from the table that majority of the students i-e $23 \%$ scored "o" and only $1(.3 \%)$ students achieved maximum score i-e "6".

\subsection{Assessment of Scheduling (Items 26-28)}

The skill of Scheduling is one of the dimensions of Critical thinking skill. Multiple choice items ranging from 26-28 were used by the researcher to analyze the skill of Scheduling. Maximum score for the skill of scheduling was 3. Scores achieved by the students, their frequency and percentages are given in table 8

Table 8: Assessment of scheduling (items 26-28)

\begin{tabular}{|l|l|l|}
\hline Achieved Scores & Frequency $(\mathrm{N})$ & Percentage $\%$ \\
\hline o & 146 & 48.7 \\
\hline 1 & 113 & 37.7 \\
\hline 2 & 39 & 13.0 \\
\hline 3 & 2 & .7 \\
\hline Total & 300 & $100 \%$ \\
\hline
\end{tabular}

Table 8 shows that out of 300 students, there are $146(48.7 \%)$ students who scored "o" on questions comprised of scheduling skill. Table reflected that 113(37.7\%) students scored "1". 39(13.0\%) students scored " 2 " and only $2(.7 \%)$ students scored " 3 " from the maximum score of 3 on the questions related to scheduling . Table reflects that majority of the students i.e., $48.7 \%$ at scored "o" and only .7\% students scored " 3 " from maximum score i-e 3 .

\subsection{Assessment of Analyze the Implied Relations}

Analysis of implied relation is one of the dimensions of Critical Thinking Skills. Multiple choice items ranging from 29-33 in critical thinking skills test are used to analyze students' skill of analyzing implied relations. Maximum score for sequencing was 5. Scores achieved, their frequency and percentages are given in table 9 . 
Table 9: Assessment of analyzing implied relations (items 29-33)

\begin{tabular}{|l|l|l|}
\hline Achieved Scores & Frequency $(\mathrm{N})$ & Percentage\% \\
\hline $\mathrm{O}$ & 82 & $27 \cdot 3$ \\
\hline 1 & 143 & $47 \cdot 7$ \\
\hline 2 & 52 & $17 \cdot 3$ \\
\hline 3 & 14 & $4 \cdot 7$ \\
\hline 4 & 8 & 2.7 \\
\hline 5 & 1 & .3 \\
\hline Total & 300 & $100 \%$ \\
\hline
\end{tabular}

Table 9 revealed that out of 300 students, $82(27.3 \%)$ students scored "o" on the question related to the ability of analyzing implied relations in CTST. The table also showed that there are $143(47.7 \%)$ students who scored "1", 52 (17.3) students scored "2", 14(4.7\%) students scored "3", 8(2.7\%) students score " 4 " and only $1(.3 \%)$ students could score " 5 " from the maximum score of " 5 ". It is reflected from the table that majority of the students i-e $47.7 \%$ scored "1" and only $1(.3 \%)$ students could achieve maximum score i-e “5”.

\subsection{Assessment of Analysis of Situations (Items 34-36)}

Multiple choice items assessing the analysis of situation, ranging from 34-36 were used to analyze the skill of analyzing situations. Maximum score for the skill of analyzing of situation was 3 . Scores achieved by the students, their frequency and percentages are given in table 10.

Table 10: Assessment of analysis of situations (items 34-36)

\begin{tabular}{|l|l|l|}
\hline Achieved Scores & Frequency(N) & Percentage $\%$ \\
\hline o & 208 & $69 \cdot 3 \%$ \\
\hline 1 & 71 & $23.7 \%$ \\
\hline 2 & 21 & $7 \cdot 0 \%$ \\
3 & 0 & 0 \\
\hline Total & 300 & 100 \\
\hline
\end{tabular}

Table 10 shows that out of 300 students, there are $208(69.3 \%)$ students who scored "o" on questions comprised of the ability of analyzing situations. Table also reflected that $71(23.7 \%)$ students scored "1" and 21(7.0\%) students scored " 2 " from the maximum score of 3 on the questions related to situation analysis. It is reflected that majority of the students i.e., $69.3 \%$ scored "o" and only $.7 \%$ students scored " 2 " from maximum score i-e 3 .

\subsection{Assessment of Drawing Logical Conclusion}

Multiple choice items, ranging from 37-40 in critical thinking skills test (CTST) were used to analyze students' skill of drawing logical conclusion. Maximum score for skill of drawing logical conclusion was 4. Scores achieved, their frequency and percentages are presented in table 11. 
Table 11: Assessment of drawing logical conclusion skill (items 37-40)

\begin{tabular}{|l|l|l|}
\hline Achieved Scors & Frequency $(\mathrm{N})$ & Percentage $\%$ \\
\hline 0 & 157 & $52.3 \%$ \\
\hline 1 & 116 & 38.7 \\
\hline 2 & 20 & 6.7 \\
\hline 3 & 6 & 2.0 \\
\hline 4 & 1 & .3 \\
\hline Total & 300 & $100 \%$ \\
\hline
\end{tabular}

Table 11 shows that out of 300 students, 157(52.3\%) students are those who scored "o" on the question related to the ability of drawing logical conclusion in CTST. The table also revealed that there are $116(38.7 \%)$ students who scored "1", $20(6.7 \%)$ students scored "2", 6(2.0\%) students scored " 3 " and only $1(.3 \%)$ students could score " 4 " from the maximum score of " 1 ". It is quite evident from the table that majority of the students i-e $52.3 \%$ scored "o" and only $1(.3 \%)$ students could achieve maximum score i-e " 4 ”.

\subsection{Assessment of Critical Thinking Skills by Mean Scores}

Assessment of critical thinking skills using mean scores is also conducted. SPSS version 22 is used to calculate the mean scores of dimensions of critical thinking skills. Mean score in each dimension of critical thinking, minimum score, maximum score and standard deviation is given in table 12.

Table 12: Assessment of critical thinking skills by mean scores

\begin{tabular}{|l|l|l|l|l|l|l|}
\hline & $\begin{array}{l}\text { Dimensions of Critical Thinking } \\
\text { skill }\end{array}$ & Minimum & Maximum & Mean & SD. \\
\hline 1 & Argument mapping(Typologies) & 300 & $\mathrm{O}$ & 2 & .31 & .529 \\
\hline 2 & Deduction from the statements & 300 & $\mathrm{o}$ & 2 & .60 & .722 \\
\hline 3 & Analysis of assumptions & 300 & $\mathrm{O}$ & 3 & .62 & .798 \\
\hline 4 & Analysis of variables & 300 & $\mathrm{O}$ & 5 & 1.05 & 1.002 \\
\hline & Analyzing tasks \& performances & 300 & $\mathrm{O}$ & 5 & 1.25 & 1.089 \\
\hline 6 & Sequencing & 300 & $\mathrm{O}$ & 5 & 1.40 & 1.057 \\
\hline 7 & Scheduling & 300 & $\mathrm{O}$ & 3 & .66 & .726 \\
\hline 8 & Analyze the implied relations & 300 & $\mathrm{O}$ & 5 & 1.09 & .960 \\
\hline 9 & Analysis of situations & 300 & $\mathrm{O}$ & 2 & .38 & .613 \\
\hline 10 & Drawing logical conclusion & 300 & $\mathrm{O}$ & 4 & .59 & .732 \\
\hline
\end{tabular}

Table 12 shows the final picture of all the dimensions used in the Critical Thinking Skill Test (CTST). Results indicated that mean value of three dimensions names analysis, analytical reasoning and logical connection in four types of questions (Analysis of variables, analyzing tasks and performances, Sequencing and Analysis of implied relations) are higher than others but this difference is minor. The results of Critical thinking skill test (CTST) is concluded in the table 13 
Table 13: Descriptive statistics of student's achievement on critical thinking skills test

\begin{tabular}{|l|l|l|l|l|l|}
\hline $\begin{array}{l}\text { Number of } \\
\text { students }\end{array}$ & $\begin{array}{l}\text { CTST Total } \\
\text { Marks }\end{array}$ & $\begin{array}{l}\text { Minimum } \\
\text { Achieved score }\end{array}$ & $\begin{array}{l}\text { Maximum } \\
\text { Achieved score }\end{array}$ & $\begin{array}{l}\text { Mean value of } \\
\text { achieved score }\end{array}$ & $\begin{array}{l}\text { Standard- } \\
\text { deviation }\end{array}$ \\
\hline 300 & 40 & 2 & 22 & 7.94 & 2.792 \\
\hline
\end{tabular}

Table 13 shows the results and variation in results of Critical Thinking skill test (CTST) scores achieved by the students. Table reveals that minimum score achieved by the students are " 2 " whereas maximum score in the test are "22" out of total marks i-e"40". The mean achieved score is "7.94" with the standard deviation of 2.792 in Critical thinking skill test (CTST) and it reflects weak performance of higher secondary students.

\section{Findings}

The present study focused on the assessment of critical thinking skills of students at higher secondary level in Punjab, Pakistan. The assessment of critical thinking skills on following dimensions of critical thinking skill was carried out in this research study i.e., analysis of argument mapping, analysis of logical deductions, analysis of assumptions, analysis of variables, analysis of tasks and performance, sequencing, scheduling, analysis of implied relations, analysis of situations and drawing logical conclusions. The study revealed that majority of students scored o in the following dimensions of critical thinking skills test i.e, argument mapping 218(72.7\%), logical deductions , 162(54\%), analysis of assumptions ,161(53.7\%), analysis of task and performance, 93 (31\%), scheduling, 146 (48.7\%), analysis of situation, 208 (69.3\%), drawing logical conclusions, 157(52.3\%). The study also revealed that out of ten dimensions of critical thinking skills in this study, the following four dimensions i.e., argument mapping, deductions from the statements ,analysis of situation and drawing logical conclusions did not get the maximum score from students participated in the study. It is concluded in the study that argument mapping dimension of the critical thinking skill have least mean score (.31) and sequencing has the highest mean score (1.41). the overall mean achieved score was .794 that represents a very low level of critical thinking skills among students at higher secondary level in the province of Punjab, Pakistan. Therefore, the study concluded that performance of students on ten dimensions of critical thinking skill test is very low at higher secondary level in Punjab, Pakistan. The findings are in line with the findings of research study by Bitner-Corvin and Betty (1988)., concluded that a significant percentage of students in grades six through twelve were neither logical nor critical thinkers. Saido, Siraj, Nordin and Al-Amedy (2018) stated same findings that represents the lower performance of students on critical thinking skill test

\section{Implications}

This is put forward, in the light of the findings of present study, that implications may include: first, the dire need of implementing the policy and education reforms at higher secondary level of education. Curriculum reforms' implementation may be monitored at higher secondary level. Teacher training, to foster critical thinking skills, among students might also be taken into consideration. Assessment practices that ask the reflection of critical thinking skills from students might also be taken up at higher secondary level in Punjab, Pakistan. Research studies might be carried out to assess the gap between theory of critical thinking skills and practice. Research studies may also be carried out the bridge the gap between policy, planning, reforms and its implementation in classrooms. The present study on focused on the quantitative results, a qualitative and more depth analytical study can be carried out to cater the need of knowing the actual situation regarding critical thinking skills of 
students at higher secondary level. Further, research studies may also be carried out to include the teachers who are engaged in teaching. Different innovative teaching methodologies can be used to cater the need of development of critical thinking skills among students.

\section{References}

Akhtar, M., \& Saeed, A. (2018). Teaching of mathematics: A comparative analysis of secondary school certificate (grade $\mathrm{x}$ ) and general certificate of education (o-level) courses of studies in Karachi. WALIA J, 34(1), 43-51.

Angel, B. F., Duffey, M., \& Belyea, M. (2000). An evidence-based project for evaluating strategies to improve knowledge acquisition and critical-thinking performance in nursing students. Journal of Nursing Education, 39, 219-228.

Beeken, J. E., Dale, M. L., Enos, M. F., \& Yarbrough, S. (1997). Teaching critical thinking skills to undergraduate nursing students. Nurse Educator, 22, 37-39.

Bellaera, L., Debney, L., \& Baker, S. T. (2018). Subject Comprehension and Critical Thinking: An Intervention for Subject Comprehension and Critical Thinking in Mixed-Academic-Ability University Students. The Journal of General Education, 65(3-4), 264-282.

Bitner-Corvin, B. L. (1988). Is the GALT a Reliable Instrument for Measuring the Logical Thinking Abilities of Students in Grades Six through Twelve?.

Care, E., Kim, H., Vista, A., \& Anderson, K. (2018). Education System Alignment for 21st Century Skills: Focus on Assessment. Center for Universal Education at The Brookings Institution.

Chenoweth, L. (1998). Facilitating the process of critical thinking for nursing. Nurse Education Today, 18, 281-292

Colucciello, M. L. (1997). Critical thinking skills and dispositions of baccalaureate nursing students -- a conceptual model for evaluation. Journal of Professional Nursing,13(4), 236-45.

Cottrell, S. (2017). Critical thinking skills: Effective analysis, argument and reflection. Macmillan International Higher Education.

Cravener, P. A. (1997). Promoting active learning in large lecture classes. Nurse Educator, 22, 21-26.

Di Vito-Thomas, P. (2000). Identifying critical thinking behaviors in clinical judgments. Journal for Nurses in Staff Development, 16, 174-180.

Ennis, R. H. (1996). Critical thinking dispositions: Their nature and assessability. Informal logic, 18(2), 165-182.

Facione, P. A., Facione, N. C., \& Giancarlo, C. A. F. (2001). California critical thinking disposition inventory: CCTDI. California Academic Press.

Gul, R., Cassum, S., Ahmad, A., Khan, S., Saeed, T., \& Parpio, Y. (2010). Enhancement of critical thinking in curriculum design and delivery: A randomized controlled trial for educators. Procedia-Social and Behavioral Sciences, 2(2), 3219-3225.

Gulzar, K., \& Mahmood, N. (2018). Appraising adequacy of standard based curriculum 2006 and allied secondary school mathematics textbooks for higher order thinking skills (HOTS) in the Punjab, Pakistan. Pakistan Journal of Education, 35(3), 1-18.

Iqbal, P., \& Almani, A. S. (2018). Secondary school curriculum in Pakistan: A challenging educational issue. Grassroots, 48(2).

Lai, E. R. (2011). Critical thinking: A literature review. Pearson's Research Reports, 6, 40-41.

Mahmood, M., \& Aziz, S. (2018). Curriculum development process at secondary level: analysis of existing situation in Pakistan and proposing a model. Journal of Research in Social SciencesJRSS, VI, 2, 64-82.

Paul, R. (2000). Critical thinking, moral integrity and citizenship: Teaching for the intellectual virtues. Knowledge, belief and character: Readings in virtue epistemology, 163-175. 
Saido, G. M., Siraj, S., Nordin, A. B. B., \& Al_Amedy, O. S. (2018). Higher order thinking skills among secondary school students in science learning. MOJES: Malaysian Online Journal of Educational Sciences, 3(3), 13-20.

Sternberg, R. J. (1986). Critical Thinking: Its Nature, Measurement, and Improvement. Washington, DC: National Institute of Education.

Tahir, K. (2018). Transformational teaching: Pakistani students' perspectives in the english classroom. International Journal of Teaching and Learning in Higher Education, 30(1), 61-69.

Terenzini, P. T., Springer, L., Pascarella, E. T., \& Nora, A. (1995). Academic and out-of-class influences on students' intellectual orientations. The Review of Higher Education, 19(1), 23-44.

Williams, R. L., \& Stockdale, S. L. (2003). High-performing students with low critical thinking skills. The Journal of General Education, 200-226. 